\title{
Matrix Metalloproteinase-9/Gelatinase B Is Required for Process Outgrowth by Oligodendrocytes
}

\author{
Luke Y. S. Oh, ${ }^{1}$ Peter H. Larsen, ${ }^{1}$ Craig A. Krekoski, ${ }^{2}$ Dylan R. Edwards, ${ }^{2}$ Frances Donovan, ${ }^{3}$ Zena Werb, ${ }^{3}$ \\ and V. Wee Yong ${ }^{1}$ \\ ${ }^{1}$ Departments of Oncology and Clinical Neurosciences, University of Calgary, Calgary, Alberta, Canada T2N 4N1, ${ }^{2 S}$ chool \\ of Biological Sciences, University of East Anglia, Norwich, United Kingdom, and ${ }^{3}$ Department of Anatomy, University of \\ California, San Francisco, San Francisco, California 94143-0452
}

\begin{abstract}
Oligodendrocytes (OLs) extend processes to contact axons as a prerequisite step in myelin formation. As the OL processes migrate toward their axonal targets, they modify adhesion to their substrate, an event that may be regulated by matrix metalloproteinases (MMPs). In the mouse optic nerve, MMP-9/ gelatinase $B$ increases during myelin formation. Although tissue inhibitor of metalloproteinase (TIMP)-3 also increases in parallel, the developing optic nerve has focally active MMPs demonstrable by in situ zymography. The distribution of proteolytic activity is similar to that of myelin basic protein, a marker of myelin formation. OLs in culture secrete MMP-9 and express
\end{abstract}

Myelin is a critical regulator of neuronal function in the CNS. Myelin formation and remyelination by oligodendrocytes (OLs) require a number of interacting factors including the availability and maturation of OLs, an appropriate microenvironment containing growth factors and extracellular matrix (ECM) molecules, and an adequate cross-talk with axons to form myelin (Ludwin, 1989; McLaurin and Yong, 1995). In human demyelinating diseases, such as multiple sclerosis (MS), significant loss of myelin and OLs occurs, eventually causing devastating neurological dysfunction. However, surviving and/or newly formed OLs, which are present around the edges of lesions in the MS brain (Ghatak, 1992; Wu et al., 1992), attempt remyelination, although the extent is often incomplete (Ghatak et al., 1989; Prineas et al., 1989; Wu et al., 1992; Raine and Wu, 1993). OL process outgrowth is an early critical step for myelination or remyelination, and before the ensheathment of axons, an OL elaborates extensive and multiple processes (Braun et al., 1988). Understanding the mechanisms by which OLs extend their processes may lead to strategies that can enhance remyelination.

In culture, OLs form processes as they mature (Gard and Pfeiffer, 1990). We have found that outgrowth of OL processes is facilitated by the astrocyte ECM (Oh and Yong, 1996). Furthermore, phorbol esters and basic fibroblast growth factor (bFGF) promote process outgrowth by OLs (Yong et al., 1991; Oh and

\footnotetext{
Received April 27, 1999; revised July 8, 1999; accepted July 15, 1999.

We thank the Multiple Sclerosis Society of Canada for support of operating funds and for a studentship to L.Y.S.O. V.W.Y. is a Senior Scholar of the Alberta Heritage Foundation for Medical Research and a Scientist of the Medical Research Council of Canada. Z.W. was supported by funds from the Ruth and Milton Steinbach Foundation and by National Institutes of Health Grant HD26732, and F.D. was supported by the Institutional National Research Service Award T32 ES07106.

Correspondence should be addressed to Dr. V. W. Yong, Departments of Oncology and Clinical Neurosciences, 3330 Hospital Drive Northwest, Calgary, Alberta, Canada T2N 4N1.

Copyright (C) 1999 Society for Neuroscience $\quad 0270-6474 / 99 / 198464-12 \$ 05.00 / 0$
}

active cell-associated metalloproteinases at the growing tips of their processes. TIMP-1 and a function-perturbing anti-MMP-9 antibody attenuate outgrowth of processes by OLs, indicating a requirement for MMP-9 in process outgrowth. Process reformation is retarded significantly in OLs cultured from MMP-9 null mice, as compared with controls, providing genetic evidence that MMP-9 is necessary for process outgrowth. These data show that MMP-9 facilitates process outgrowth by OLs in vivo and in culture.

Key words: myelination; oligodendrocyte; matrix metalloproteinase; in situ zymography; MMP knock-out; TIMPs
Yong; 1996; Bansal and Pfeiffer, 1997), by activating protein kinase C (PKC) (Althaus et al., 1992; Yong et al., 1994; Oh et al., 1997). The downstream effectors of PKC activation in OLs that promote process outgrowth, however, are poorly understood.

For OL processes to advance from the soma, it is likely that the pericellular environment will be subjected to significant remodeling by proteinases. The family of matrix metalloproteinases (MMPs) is known to degrade most, if not all, proteinaceous ECM molecules including collagen, fibronectin, laminin, and a variety of proteoglycans (Yong et al., 1998). There are at least 18 members of MMPs, which are categorized into four groups depending on substrate preference and structural differences: collagenases, gelatinases, stromelysins, and membrane-type MMPs. MMPs have been shown to be involved in physiological processes (e.g., embryogenesis, ovulation, bone growth or remodeling, and angiogenesis) and also in pathology (e.g., tumor metastasis, rheumatoid arthritis, and periodontal disease) (Woessner, 1994). In the CNS, MMPs have been studied in several conditions such as glioma invasiveness, leukocyte infiltration, and neurite outgrowth (for review, see Yong et al., 1998). Growth factors including nerve growth factor and FGFs appear to stimulate neurons to upregulate MMPs in correspondence with neurite outgrowth (Machida et al., 1989; Muir, 1994). We have reported that phorbol esters increase MMP-9 (gelatinase B) secretion by OLs in parallel with increased process extension (Uhm et al., 1998), whereas calphostin C, a selective inhibitor of PKC activation, attenuates MMP-9 production by OLs in parallel with decreased process formation. In this study, we have asked whether MMP-9 is required for process outgrowth by OLs in vitro and during myelination in vivo.

\section{MATERIALS AND METHODS}

Cell culture and drug treatment. Adult human OLs were derived from brain biopsy specimens from patients who underwent surgical resection 

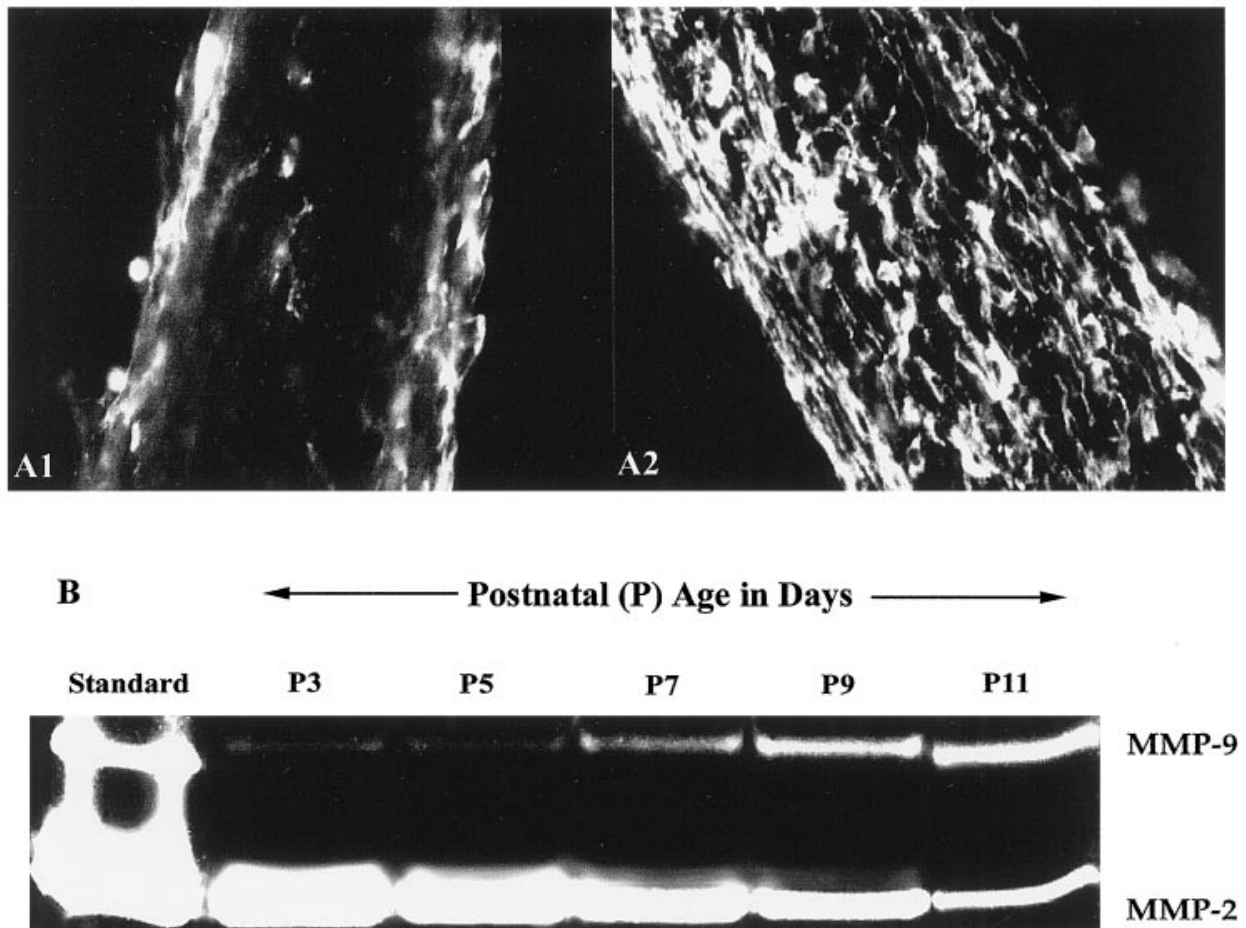

Figure 1. Expression of MMP-2 and MMP-9 during myelination in developing optic nerve. The period of myelin formation in the CD1 mouse optic nerve is shown by MBP immunofluorescence. $A 1, A 2$, Weak immunoreactivity of MBP at $\mathrm{P} 7$ is shown (A1), whereas strong MBP staining indicates active myelination at $\mathrm{P} 9(A 2)$. $B$, Gelatin zymography of optic nerve from P3 to P11 CD1 mice shows a gradual increase in MMP-9 in contrast to the decrease in MMP-2 during this period. $C$, Reverse gelatin zymography for TIMPs is shown. TIMP-3 increased in mouse optic nerve during the period of myelination (P3 to P11), whereas no significant changes in TIMP-1 or TIMP-2/-4 levels were detected.

to ameliorate drug-intractable epilepsy. Samples containing white and gray matter were of areas adjacent to, but not containing, the epileptic focus. Bovine cells were derived from the corpus callosum of adult animals obtained from a local meat-processing center. Adult, threemonth-old mice were used to obtain murine cells; unless otherwise stated, the strain was the CD1 outbred.

Cells were dissociated by trypsin digestion and isolated by Percoll gradient centrifugation according to a protocol described elsewhere (Yong and Antel, 1997). The initial cell isolates, consisting of OLs, astrocytes, and microglia, were plated onto uncoated T $25 \mathrm{~cm}^{2}$ flasks. In contrast to astrocytes and microglia, adult OLs are poorly adherent on uncoated substrate; floating cells were collected the following day and, when subjected to another round of differential adhesion, resulted in OL cultures of $>95 \%$ purity. Purified OLs were then plated onto Lab-Tek 16-well chamber slides (Nunc, Naperville, IL) or glass coverslips coated with $10 \mu \mathrm{g} / \mathrm{ml}$ poly-L-ornithine (Sigma, St. Louis, MO).

For MMP inhibition, 1,10-phenanthroline (Sigma), recombinant human tissue inhibitor of metalloproteinase (TIMP)-1 (compliments of Dr. Andy Docherty, Celltech, Slough, UK), and sheep anti-porcine MMP-9 antibody (gift of Dr. G. Murphy, University of East Anglia, Norwich, UK) were added to OL cultures $1 \mathrm{hr}$ before adding $10 \mathrm{nM} 4 \beta$-phorbol12,13-dibutyrate (PDB; LC Laboratories, Woburn, MA).

OLs were cultured in Minimum Essential Medium supplemented with $10 \%$ fetal bovine serum, $20 \mu \mathrm{g} / \mathrm{ml}$ gentamycin, and $0.1 \%$ dextrose. To collect medium conditioned by OLs for zymography, we added serumfree medium supplemented with hormones, as described elsewhere (Boutros et al., 1997).
Immunocytochemistry and analyses of process formation in vitro. Oligodendrocytes derived from adult brains were stained with an O1 monoclonal antibody that recognizes galactocerebroside, a marker for mature OLs (Sommer and Schachner, 1981; Bansal et al., 1989). Human and bovine OLs extended several thread-like processes from soma, which facilitated the counting of the percentage of O1-positive $(\mathrm{O} 1+)$ cells with processes over three soma diameters, as described previously (Yong et al., 1994; Oh and Yong, 1996). However, the processes of mouse OLs were in the form of membranous-like sheets, which did not allow the documentation of OLs with processes over a given length criterion. Thus, we used a computer-assisted technique to measure the area of processes extended out from murine OL soma. In brief, using a digital camera to acquire images and an Image pro image analysis program, we measured the total area covered by OLs (O1+ staining); this area measurement also included their nuclei. The area covered by nuclei (Hoescht-stained) was also measured. To obtain the extent of processes generated by OLs, the total measured area of $\mathrm{O} 1+$ immunoreactivity was subtracted with that of Hoescht dye staining.

Gelatin zymography and reverse gelatin zymography. Gelatin-substrate gel electrophoresis was used to detect gelatinases (Stuve et al., 1996; Uhm et al., 1998). In brief, serum-free medium conditioned by OLs was collected and mixed (1:3) with $4 \times$ gel-loading buffer. The samples were separated at $4^{\circ} \mathrm{C}$ on a $12 \%$ SDS gel containing $1 \mathrm{mg} / \mathrm{ml}$ gelatin. The gel was then washed twice and incubated overnight on a shaker at room temperature with rinse buffer containing 2.5\% Triton X-100, $50 \mathrm{~mm}$ Tris- $\mathrm{HCl}, \mathrm{pH} 7.5$, and $5 \mathrm{~mm} \mathrm{CaCl}$. The Triton $\mathrm{X}-100$ wash extracted SDS, allowing gelatinases to renature within the gel. The following day, 


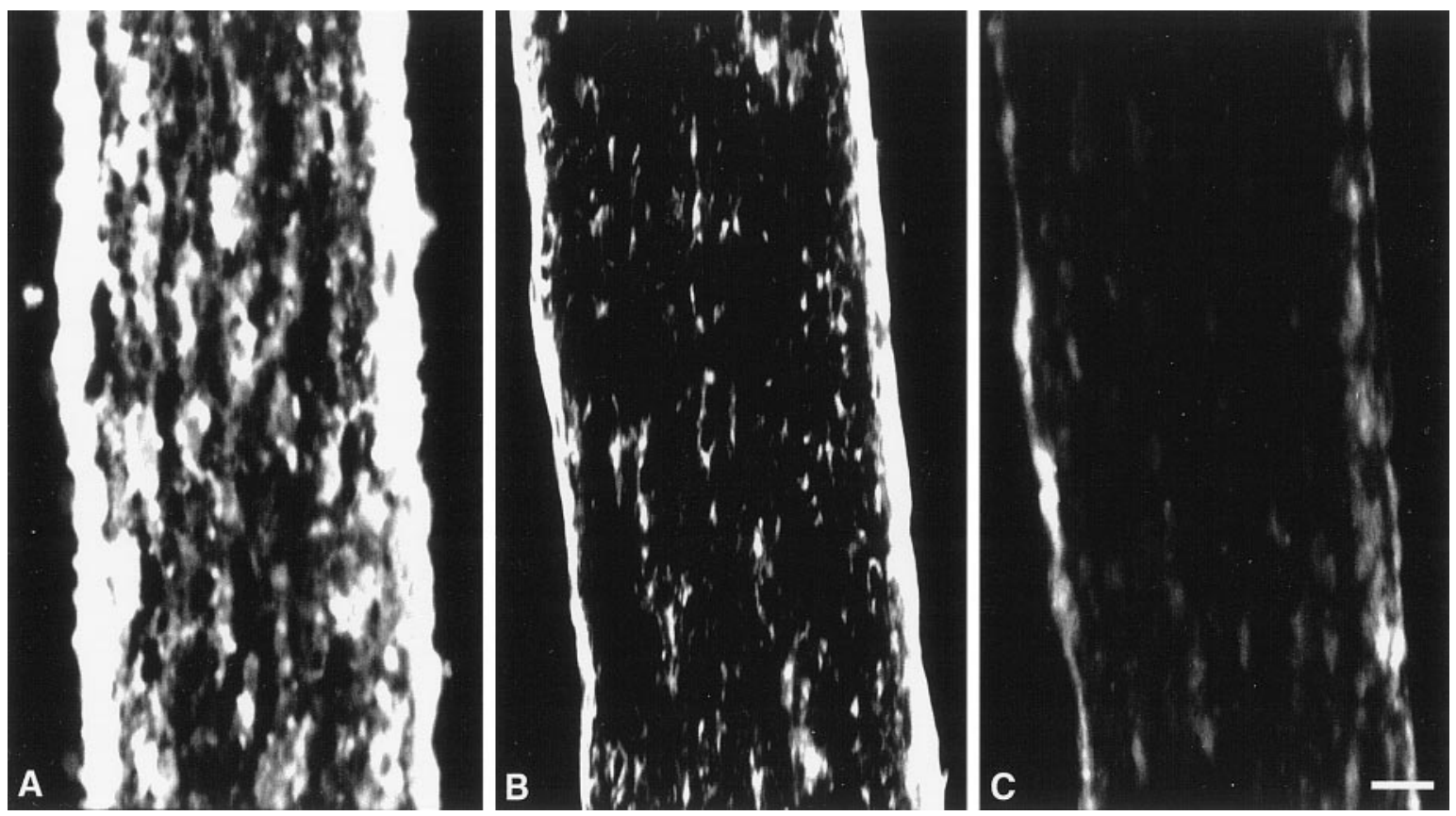

Figure 2. Localization of MMP activity in developing optic nerve in vivo by in situ zymography. A cryostat section of $\mathrm{P} 9$ mouse optic nerve shows proteolytic activity of MMPs by in situ zymography $(A)$. Localization of gelatinolytic activity $(A)$ was reduced in the presence of TIMP-1 $(500 \mathrm{ng} / \mathrm{ml}$; $B)$ or 1,10-phenanthroline $(50 \mu \mathrm{M} ; C)$. Scale bar, $50 \mu \mathrm{m}$.

each gel was incubated with reaction buffer containing $50 \mathrm{~mm}$ Tris- $\mathrm{HCl}$, $\mathrm{pH} 7.5$, and $5 \mathrm{~mm} \mathrm{CaCl}_{2}$ for $16-18 \mathrm{hr}$ at $37^{\circ} \mathrm{C}$, to allow proteinases to degrade gelatin in their immediate vicinity. After rinsing with water, each gel was stained with Coomassie blue for $4 \mathrm{hr}$. Incubation of the gel with destaining solution [acetic acid: methanol: water (1:3:6)] revealed the expression of gelatinases as clear bands (zone of gelatin degradation) against a dark background. The identity of MMPs was based on their molecular weight and was confirmed by Western blot and immunodepletion experiments (Uhm et al., 1998).

In some experiments, the whole-cell lysate of OLs was used for zymography. To obtain lysates, we removed the medium of OLs and washed the cells once with PBS. Extraction buffer, containing 1\% Triton $\mathrm{X}-100,500 \mathrm{~mm}$ Tris-HCl, pH 7.6, $200 \mathrm{~mm} \mathrm{NaCl}$, and $10 \mathrm{~mm} \mathrm{CaCl}_{2}$, was then added. The lysate was collected, and $20 \mu \mathrm{g}$ of total protein was loaded per lane.

For gelatin zymography of the developing mouse optic nerves, homogenates of early postnatal CD1 mouse optic nerves were used. The optic nerves from mice were carefully dissected and quick-frozen at $-80^{\circ} \mathrm{C}$. At least five mice per age group were combined to prepare an optic nerve sample. The optic nerves were homogenized in extraction buffer (described above), and the total protein content was analyzed by Bradford protein assays. Thirty micrograms of total protein from each sample was mixed with $4 \times$ gel-loading buffer and separated on SDS-polyacrylamide gels as described above.

Reverse gelatin zymography was used to reveal physiological inhibitors of MMPs (i.e., TIMP-1 to -4). The gel was prepared in the same manner described for gelatin zymography with the exception that gelatinases were also added to the SDS-gelatin gel. After electrophoresis and during incubation of the gel with the reaction buffer described above, the impregnated gelatinases degrade gelatin throughout the gel except at areas where the inhibitory TIMPs are located; these areas remain as dark blue bands after Coomassie blue staining of gels and destaining. In general, the sensitivity of reverse zymography (enzyme-based reaction) for TIMPs is superior to that of Western blots (Leco et al., 1994; Kossakowska et al., 1998).

In situ zymography in vivo and in vitro. To localize net gelatinolytic activity of MMPs by in situ zymography, FITC-labeled DQ gelatin that is intramolecularly quenched [available in a gelatinase/collagenase assay kit (EnzChek; Molecular Probes, Eugene, OR)] was used as a substrate for degradation by gelatinases. Proteolysis by gelatinases yields cleaved gelatin-FITC peptides that are fluorescent. The localization of fluorescence indicates the sites of net gelatinolytic activity. Optic nerves of postnatal day 7 and 9 mice were dissected and rinsed in cold PBS to remove blood vessels and debris. The optic nerves were then immersed in ornithine carbamyl transferase (OCT) compound (Tissue-Tek, Torrance, CA) and quick-frozen into a block on dry ice. The optic nerves in the OCT block was cut into $8 \mu \mathrm{m}$ sections using a cryostat (Leica, Wetzler, Germany) and collected sequentially. The optic nerve sections were stored at $-80^{\circ} \mathrm{C}$ until used for in situ zymography and immunohistochemistry. For in situ zymography, sections were thawed and incubated with reaction buffer $\left(0.05 \mathrm{M}\right.$ Tris- $\mathrm{HCl}, 0.15 \mathrm{M} \mathrm{NaCl}, 5 \mathrm{mM} \mathrm{CaCl}_{2}$, and 0.2 $\mathrm{mM} \mathrm{NaN}_{3}, \mathrm{pH}$ 7.6) containing $40 \mu \mathrm{g} / \mathrm{ml}$ DQ gelatin overnight. At the end of the incubation period and without fixation or washes, gelatinolytic activity of MMPs was localized and photographed by fluorescence microscopy. Images were acquired by a Spot digital camera with a computer-imaging program (Image-Pro Plus). Adjacent cryostat sections were fixed with $4 \%$ paraformaldehyde, followed by immunohistochemistry for myelin basic protein (MBP; Serotec, Oxford, UK) or glial fibrillary acidic protein (GFAP; Dako, Scarborough, Ontario, Canada) as described previously (Balasingam and Yong, 1996).

To determine in situ gelatinolytic activity of OLs in culture, cells were plated onto coverslips and treated with $10 \mathrm{~nm}$ PDB to promote their process extension. Live cells were stained with the $\mathrm{O} 1$ antibody as described above, then washed with PBS, and incubated with the in situ zymography reaction buffer (described above) overnight at $37^{\circ} \mathrm{C}$. We noted that if cells were prefixed, this substantially reduced their capacity to degrade gelatin-FITC, likely because cells needed to be alive to perform their proteolytic function. However, if cells were fully functional, the intensity of gelatinolytic signal was also reduced, presumably because cells phagocytose the gelatin substrate and cleave it intercellularly. As a compromise, $0.2 \mathrm{~mm}$ sodium azide was incorporated into the reaction buffer and incubated with live cells. Under these conditions the cells shut down metabolism, retain $\mathrm{O} 1$ staining, but still enable cell surface-associated gelatinolysis to occur.

As a negative control for in situ zymography, $50 \mu \mathrm{M}$ 1,10phenanthroline or $500 \mathrm{ng} / \mathrm{ml}$ TIMP-1 was added to the reaction buffer before the buffer was applied to the cells or to the frozen cryostat optic nerve sections to inhibit metalloproteinases.

Statistical analyses. Because multiple treatments, or multiple concentrations of each treatment, were used in all experiments, a one-way ANOVA with Tukey-Kramer multiple comparisons was used for statistical analyses. 

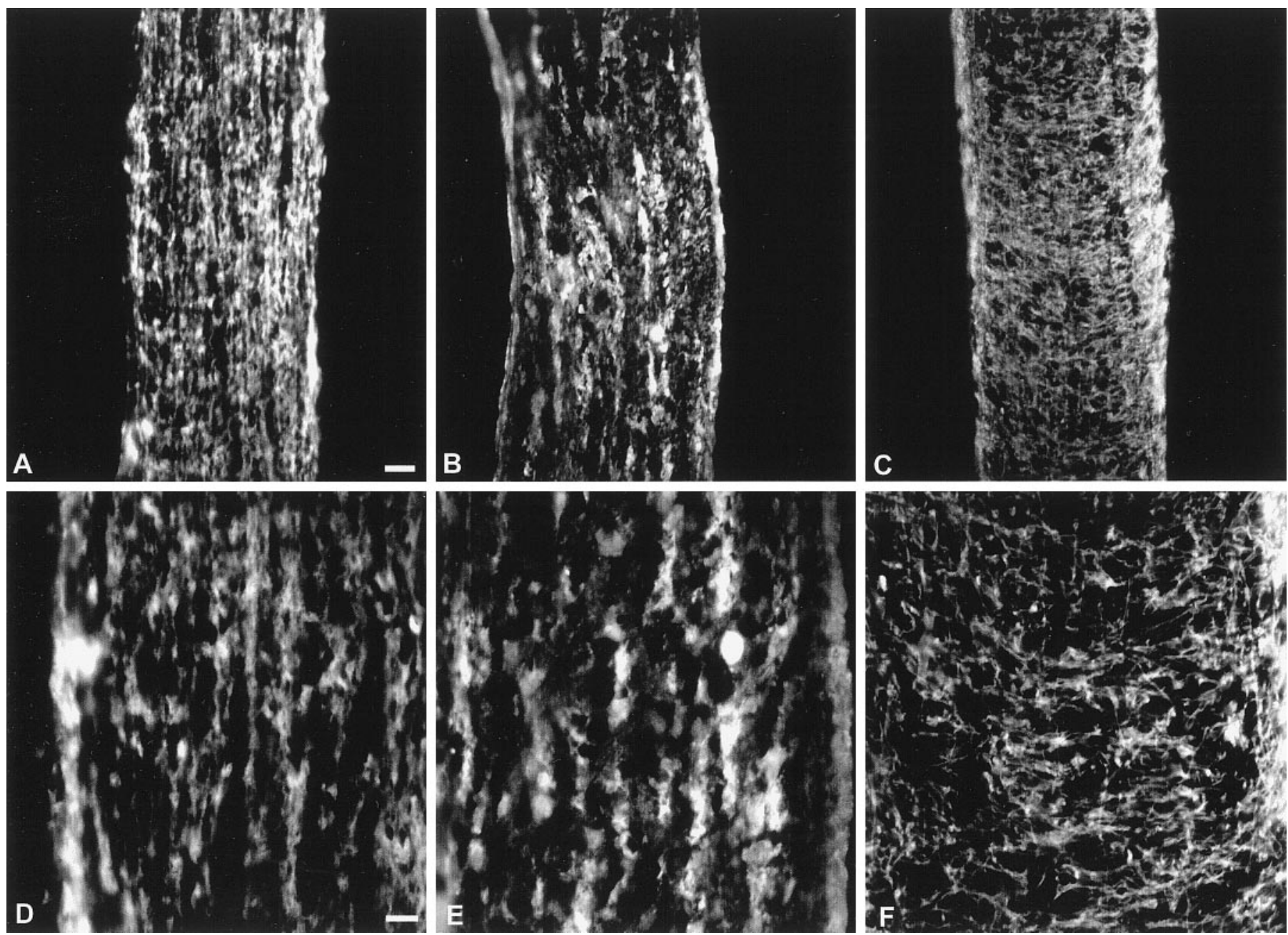

Figure 3. Comparison of localization of gelatinase activity with MBP or GFAP immunoreactivity in developing optic nerve. Immunohistochemistry of $\operatorname{MBP}(A, D)$ and GFAP $(C, F)$ and in situ zymography $(B, E)$ of $\mathrm{P} 9$ mouse optic nerve show that the pattern of proteolytic activity shown by in situ zymography appeared to be similar to that of longitudinal MBP immunoreactivity. In contrast, GFAP immunoreactivity was mainly perpendicular to that of MBP and in situ zymography $(C, F)$. Scale bars: $A-C, 100 \mu \mathrm{m} ; D-F$,Please verify? $50 \mu \mathrm{m}$.

\section{RESULTS}

MMP-9 and TIMPs are expressed in mouse optic nerve during myelin formation

During myelination, oligodendrocytes extend processes, a function similar to axonal outgrowth that has been shown to involve altered interactions with ECM regulated by proteolysis (Monard, 1988; McGuire and Seeds, 1990; Muir, 1994). In the mouse optic nerve, myelin formation takes place between postnatal day 5 (P5) and P12 (Foran and Peterson, 1992). We observed that myelin formation in the CD1 outbred mouse optic nerve increases dramatically between $\mathrm{P} 7$ and P9. MBP immunoreactivity, a marker for myelin formation, was low on $\mathrm{P} 7$ and abundant on P9 (Fig. 1A).

MMP-9 levels paralleled the progressive developmental myelination in the mouse optic nerve. By gelatin zymography assays we found that there was a gradual increase in MMP-9 levels from P3 to P11 mouse optic nerves, whereas expression of MMP-2 decreased (Fig. $1 B$ ). MMP activity is regulated not only by expression and activation of the enzymes but also by endogenous inhibitors. During developmental myelination (Fig. 1C), we observed no significant changes in expression of TIMP-1 (28 kDa) or TIMP-2/-4 (21 and $22 \mathrm{kDa}$, respectively) by reverse gelatin zymography. In contrast, TIMP-3 (24 kDa) increased from P3 to P11.

\section{A novel in situ zymography method reveals that active MMPs are present during myelin formation in vivo}

The observation that both MMP-9 and TIMP-3 increased during the period of myelin formation led us to ask whether there was net proteolytic activity. We developed a new in situ zymography method to demonstrate net proteolytic activity in mouse optic nerve. When frozen sections were incubated with intramolecularly fluorescein-quenched gelatin, the digestion of gelatin yielded cleaved fluorescent peptides that enabled us to locate the gelatinolytic activity. The majority of the gelatinolytic activity appeared to be associated with cells. TIMP-1 or 1,10phenanthroline significantly reduced the gelatinolytic activity (Fig. 2), indicating that the proteolytic activity was caused by MMPs. Both MMP-2 (gelatinase A) and MMP-9 (gelatinase B), which are present at this time in development, cleave gelatin. Although the assay does not discriminate between MMP-2 and MMP-9, it is likely that proteolytic activity primarily represents that of the latter, given the increase of MMP-9 during this period. Importantly, there was significant gelatinolytic activity in the P9 mouse optic nerve, at a time point when dramatic myelin formation was occurring.

Mouse optic nerve contains both OLs and astrocytes. To iden- 

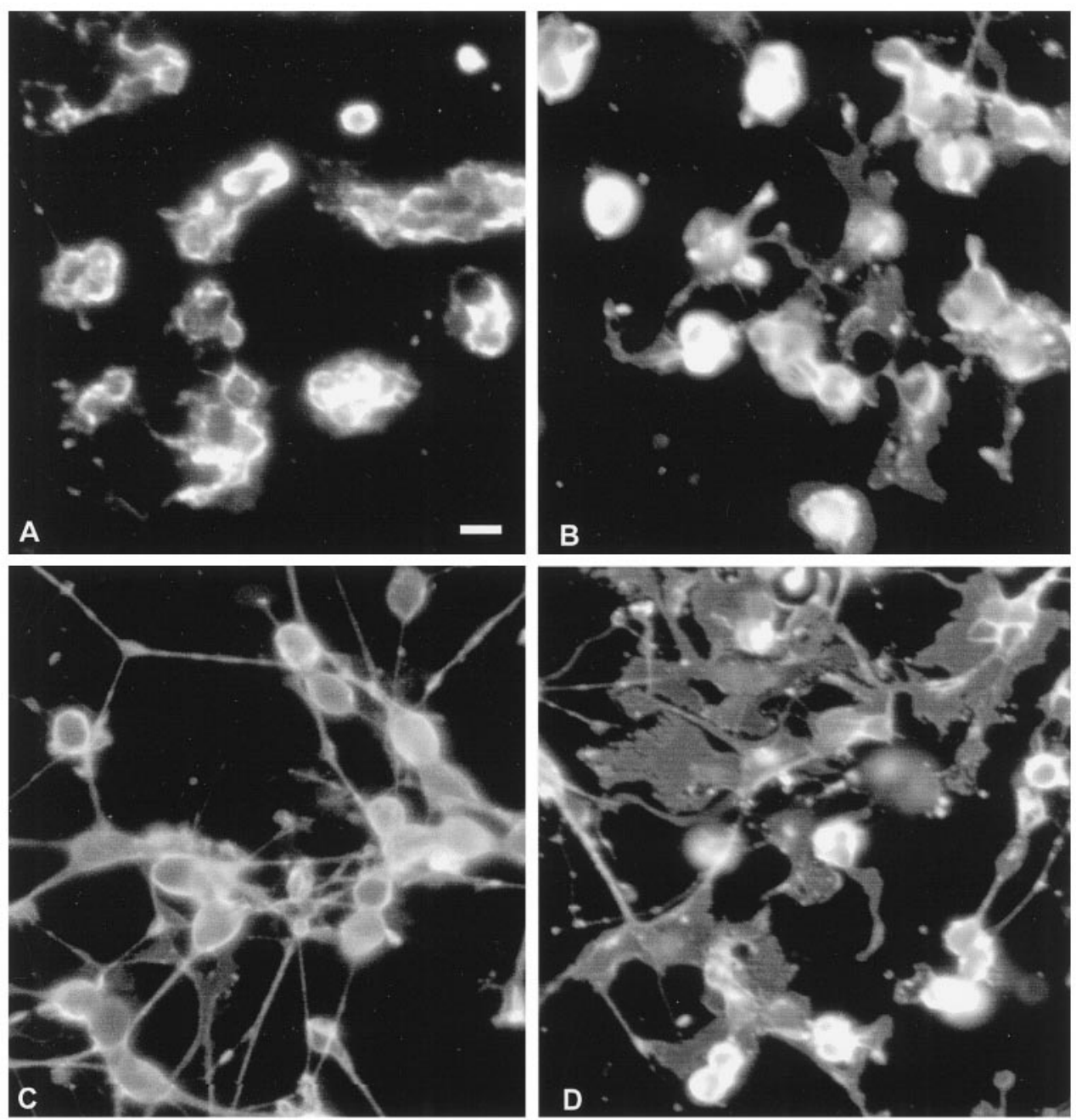

Figure 4. Morphology and MMP-9 expression by OLs. Bovine or murine OLs express MMP-9 and form processes after PDB treatment. $A, B$, Control untreated bovine $(A)$ and murine $(B)$ OLs are shown. $C, D$, In response to PDB treatment, both bovine $(C)$ and murine (D) OLs upregulate the extent of their process formation. Scale bar, $10 \mu \mathrm{m}$. $E$, The expression of MMP-9 correlates with the process outgrowth induced by PDB (shown for bovine OLs only). $F$, The conditioned medium $(C M)$ of OL cultures contains mainly pro-MMP-9, because APMA treatment of the conditioned medium $(C M+A P M A)$ converts pro-MMP-9 to the lower molecular weight active MMP-9. However, active MMP-9 was detected in OL cell lysate (Lysate).
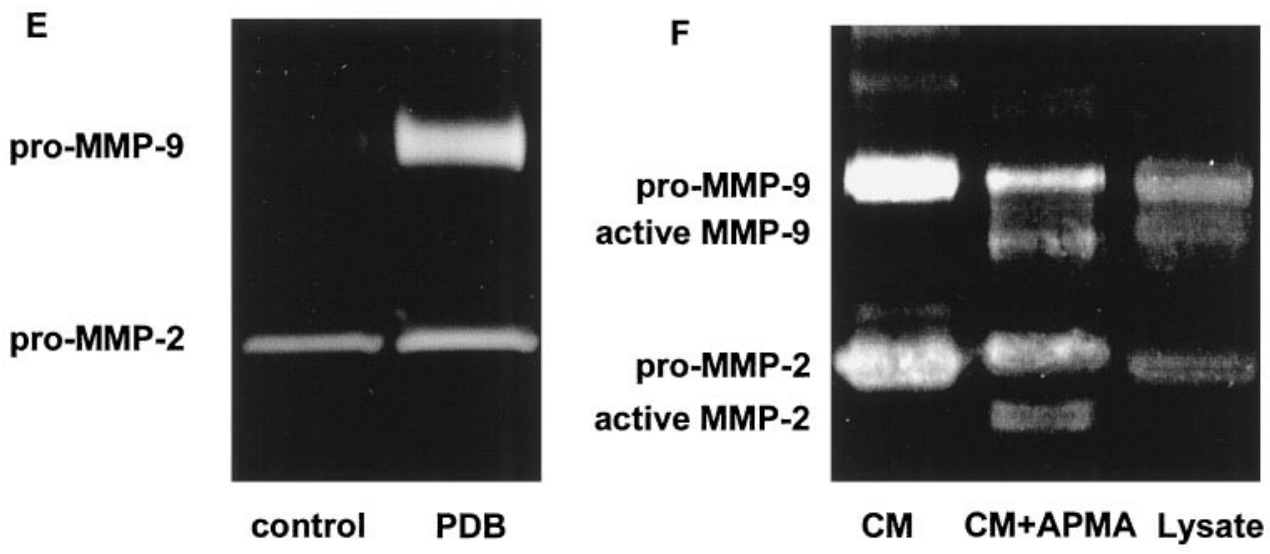

tify the cellular source of the gelatinolytic activity, we subjected sequential cryostat frozen sections to immunohistochemistry specific for OLs (MBP) or astrocytes (GFAP) or to in situ zymography; it was not possible to perform both manipulations on the same section because the processing used in immunohistochemistry often interfered with the in situ zymography signals or destroyed the gelatinolytic activity. The distribution of OLs, as shown by MBP immunoreactivity, was similar to that of gelatinolytic activity, longitudinally along the mouse optic nerve (Fig. 3). In contrast, astrocytes, visualized with GFAP labeling, are dis- tributed perpendicular to the gelatinolytic signal. These data indicate that much of the gelatinolytic activity is expressed on OLs and their processes.

\section{Oligodendrocytes in culture express active MMPs}

We have investigated whether MMP expression found during developmental myelin formation in vivo is recapitulated during process outgrowth in OLs isolated from bovine, human, and mouse brains (Fig. 4). MMP-9 production, process extension, and inhibition of process extension by MMP inhibitors occurred when 

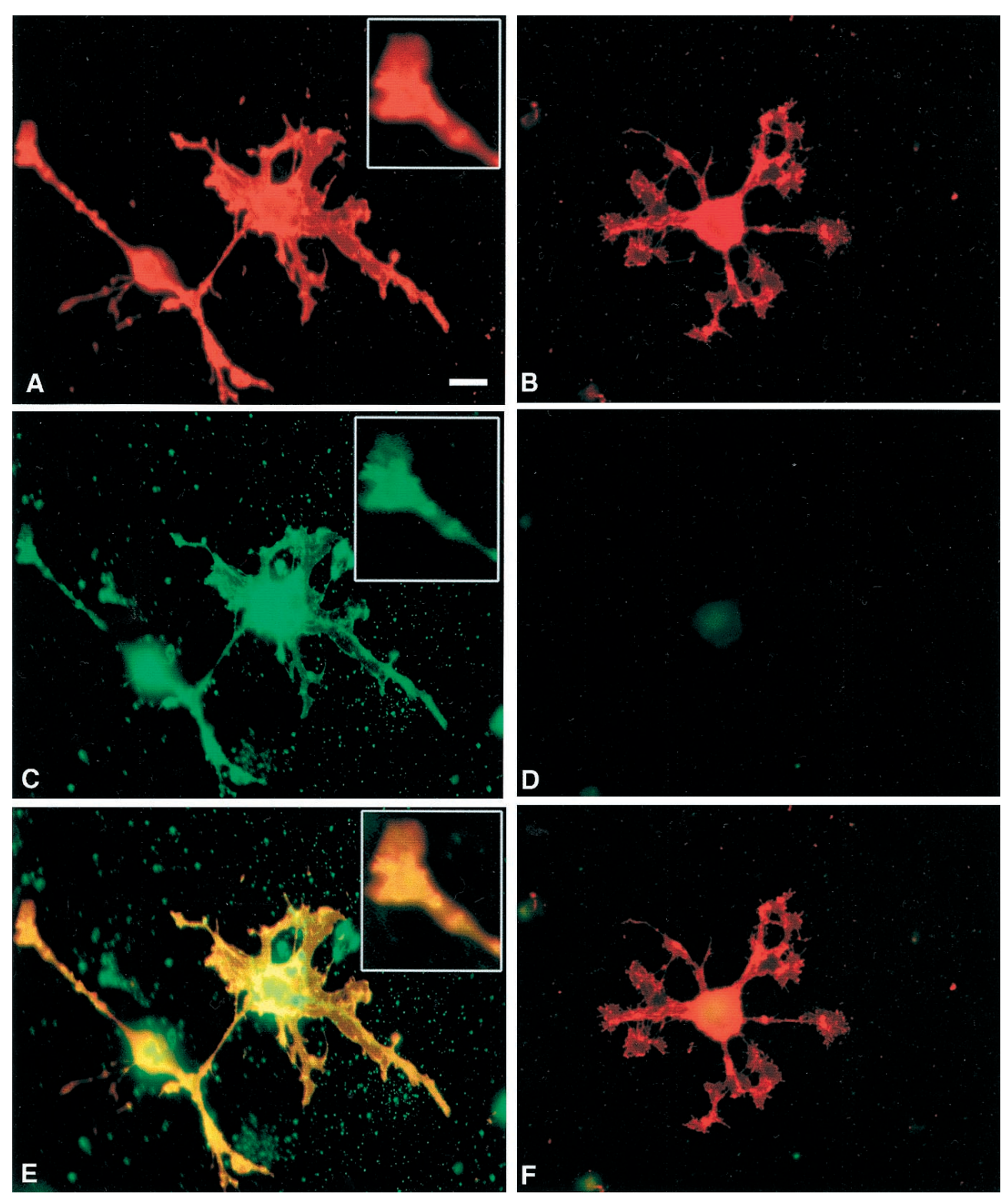

Figure 5. Localization of MMP activity in OLs in culture by in situ zymography. $A, B, \mathrm{O} 1+\mathrm{OLs}$ treated with $\mathrm{PDB}$ to induce process formation are shown. $C, D$, Net proteolytic activity of MMP $(C)$ was localized on OL soma, processes, and the tip of a process (inset of $A, C, E)$, whereas in the presence of 1,10-phenanthroline $(50 \mu \mathrm{M})$, the MMP activity by OLs was inhibited $(D)$. E, A superimposed image overlapping signal from $\mathrm{O} 1$ immunoreactivity $(A)$ and in situ zymography $(C)$ is shown. $F$, The corresponding superimposed image of $B$ and $D$ is shown. Scale bar, $10 \mu \mathrm{m}$.

OLs were cultured on poly-L-lysine- or poly-L-ornithine-coated surfaces (L. Y. S. Oh and V. W. Yong, unpublished observation) or on astrocyte-derived ECM (Uhm et al., 1998). Therefore, all subsequent experiments were performed using a poly-Lornithine-coated surface as the cell substrate.

Although mouse OLs had a more mature (membranous sheets) morphology compared with their (thread-like processes) bovine (Fig. 4) or human counterparts (Uhm et al., 1998), OLs from all species increased process formation when treated with PDB, an activator of protein kinase C (Yong et al., 1994). MMP-9 secretion accompanied process outgrowth by OLs (Fig. 4A-E). Based on a molecular weight determination ( $\sim 92 \mathrm{kDa}$ for human or bovine and $105 \mathrm{kDa}$ for murine samples), the MMP-9 detected in the conditioned medium of OL cultures was that of the zymogen. Incubation of OL-conditioned medium with $1 \mathrm{~mm}$ 4-aminophenyl mercuric acetate (APMA) at $37^{\circ} \mathrm{C}$ for $15 \mathrm{~min}$ converted the zymogen form of MMPs to active forms of MMPs detectable at lower molecular weight in zymograms $(\sim 85 \mathrm{kDa}$ for active MMP-9) (Fig. 4F). The absence of detectable active MMP-9 in the conditioned medium is likely because cells confine the acti- vation of MMPs to the pericellular environment, thereby preventing widespread proteolysis (Murphy and Knauper, 1997). Nevertheless OLs appear to produce cell-associated active MMP-9, which was seen in the cell lysate of OLs by gelatin zymography (Fig. 4F). It should be noted that the molecular weight of APMA-activated pro-MMP-9 from conditioned medium appears to be lower than that of the active band obtained from cell lysates; the latter could be intermediate active forms of MMP-9. This could be resolved by APMA treatment of the lysate samples, which we did not conduct. Intermediate forms of active MMPs are known to exist (for review, see Nagase, 1997).

To address where in the OL active proteinases are produced, we next used in situ zymography, coupled with counterstaining of OLs with an O1 antibody that recognizes galactocerebroside, a marker for mature OL (Fig. 5). We found net gelatinolytic activity of MMPs on the processes and on the advancing tip of OL processes (Fig. 5A,C,E), in keeping with the postulate that these areas advance the OL boundaries. That the in situ proteolytic signals from OLs in vitro is metalloproteinase in nature is indicated by the finding that the proteolysis is inhibited in the pres- 


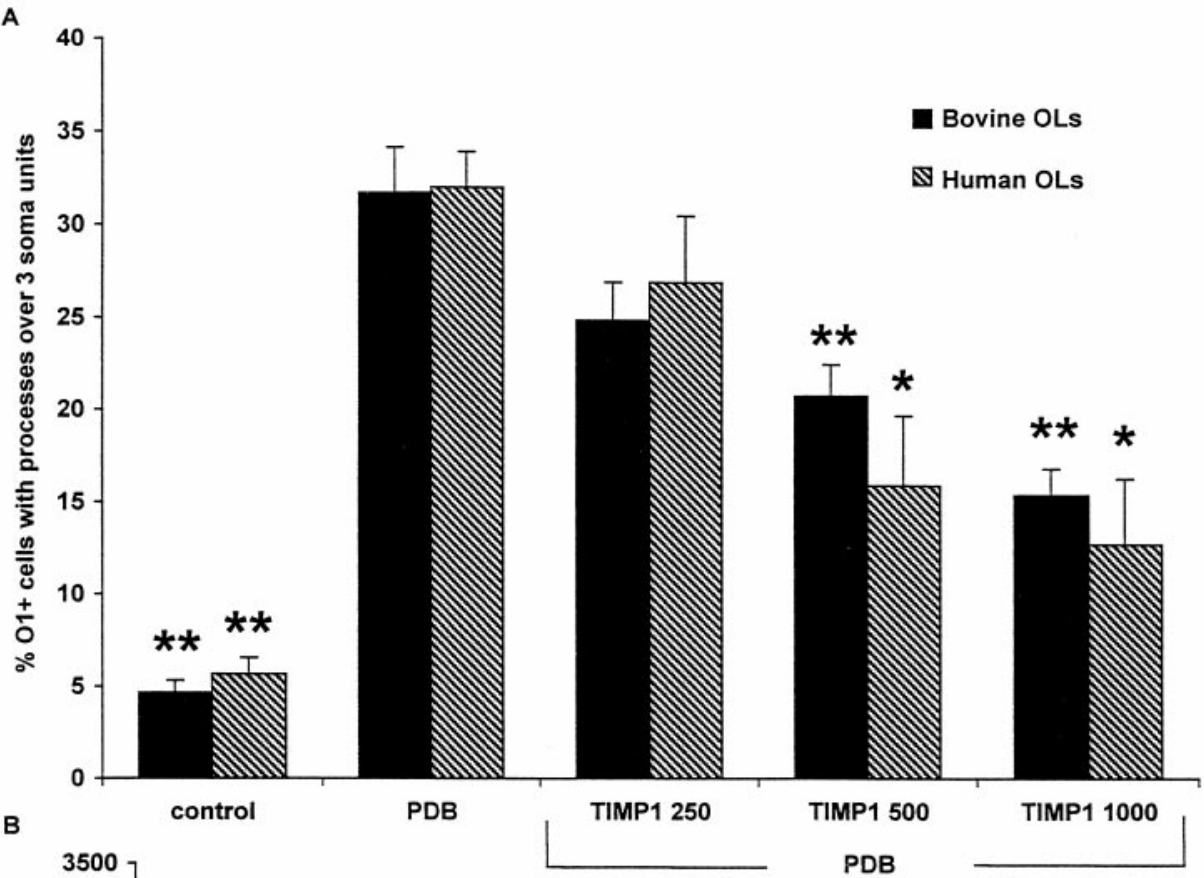

Figure 6. Effects of TIMP-1 on process outgrowth by OLs. The process outgrowth induced by $10 \mathrm{~nm}$ PDB in human and bovine OLs $(A)$ and in mouse OLs $(B)$ was inhibited by recombinant human TIMP-1. TIMP-1 concentrations are given in nanograms per milliliter. ${ }^{*} p<0.01$ and ${ }^{* *} p<0.001$ compared with PDB treatment alone.

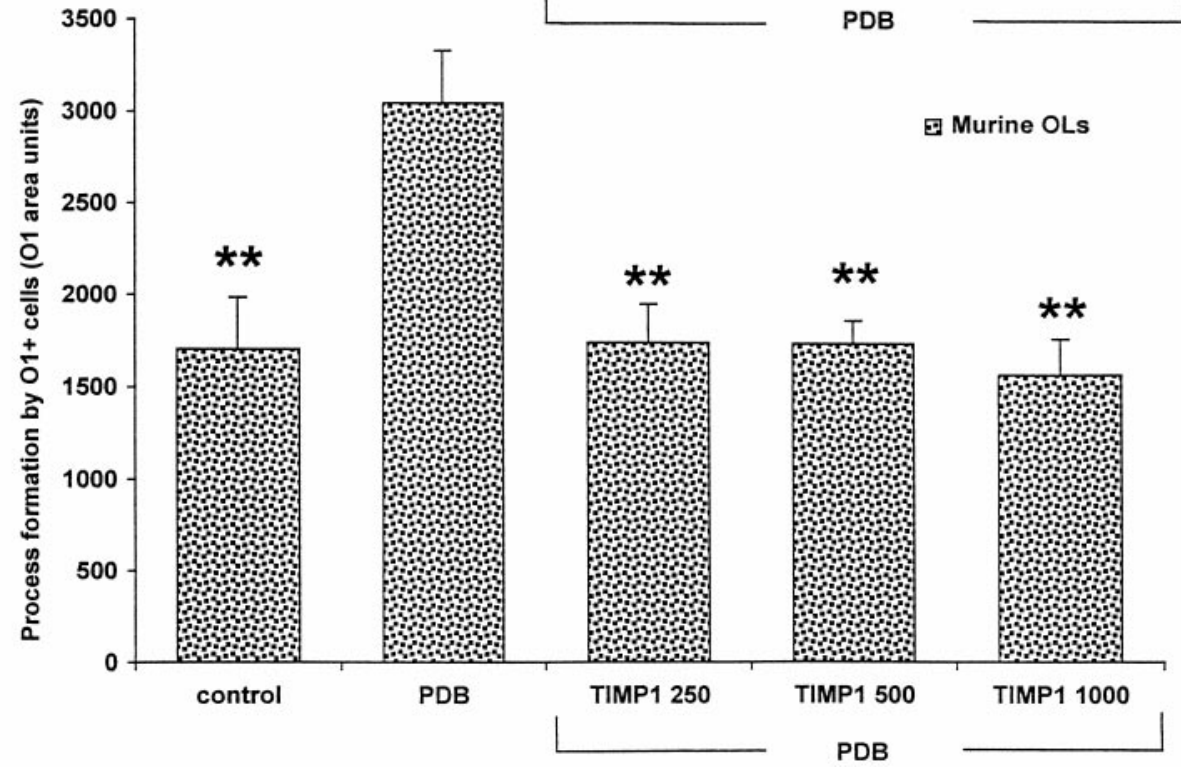

ence of 1,10-phenanthroline (Fig. 5B,D,F). A surprising observation is that net gelatinolytic activity was also manifest in a uniform manner around the OL soma. That the distribution of uniform gelatinolytic activity is peculiar to OLs is indicated by localized and punctate distribution of gelatinolytic activity in another cell type, baby hamster kidney (BHK) cells (Oh and Yong, unpublished observation). Thus, depending on the cell type, MMPs are used at different locations.

In summary, the results of gelatin and in situ zymographies indicate that activation and use of MMPs occur in the pericellular environment of the OL.

\section{MMP-9 facilitates process outgrowth by oligodendrocytes}

We next asked whether the gelatinolytic activity and process extension are mechanistically related by blocking MMP function. TIMP-1, a physiological inhibitor of MMP activity, reduced the process outgrowth stimulated by PDB treatment in human, bo- vine, and mouse OLs (Fig. 6). Moreover, most of the MMP action could be attributed to MMP-9. Addition of a functionblocking antibody to MMP-9 (Librach et al., 1991) reduced process outgrowth of bovine OLs to the level where few OLs bore notable long processes (Fig. 7). However, the addition of soluble MMP-9 to OLs did not induce process outgrowth (data not shown). These results indicate that MMP-9 facilitates process outgrowth by OLs and that OLs from human, bovine, and mouse share this common mechanism for process outgrowth.

\section{Process outgrowth is deficient in OLs derived from MMP-9 null mice}

If MMP-9 plays a key role in OL process outgrowth, are OLs in MMP-9 null mice (Vu et al., 1998) defective in process formation or myelination? To address this, we immunostained the optic nerves of MMP-9 null mice for MBP as a marker of myelin formation. Figure 8 shows that the development of MBP in the optic nerve of MMP-9 null mice is comparable with that of 

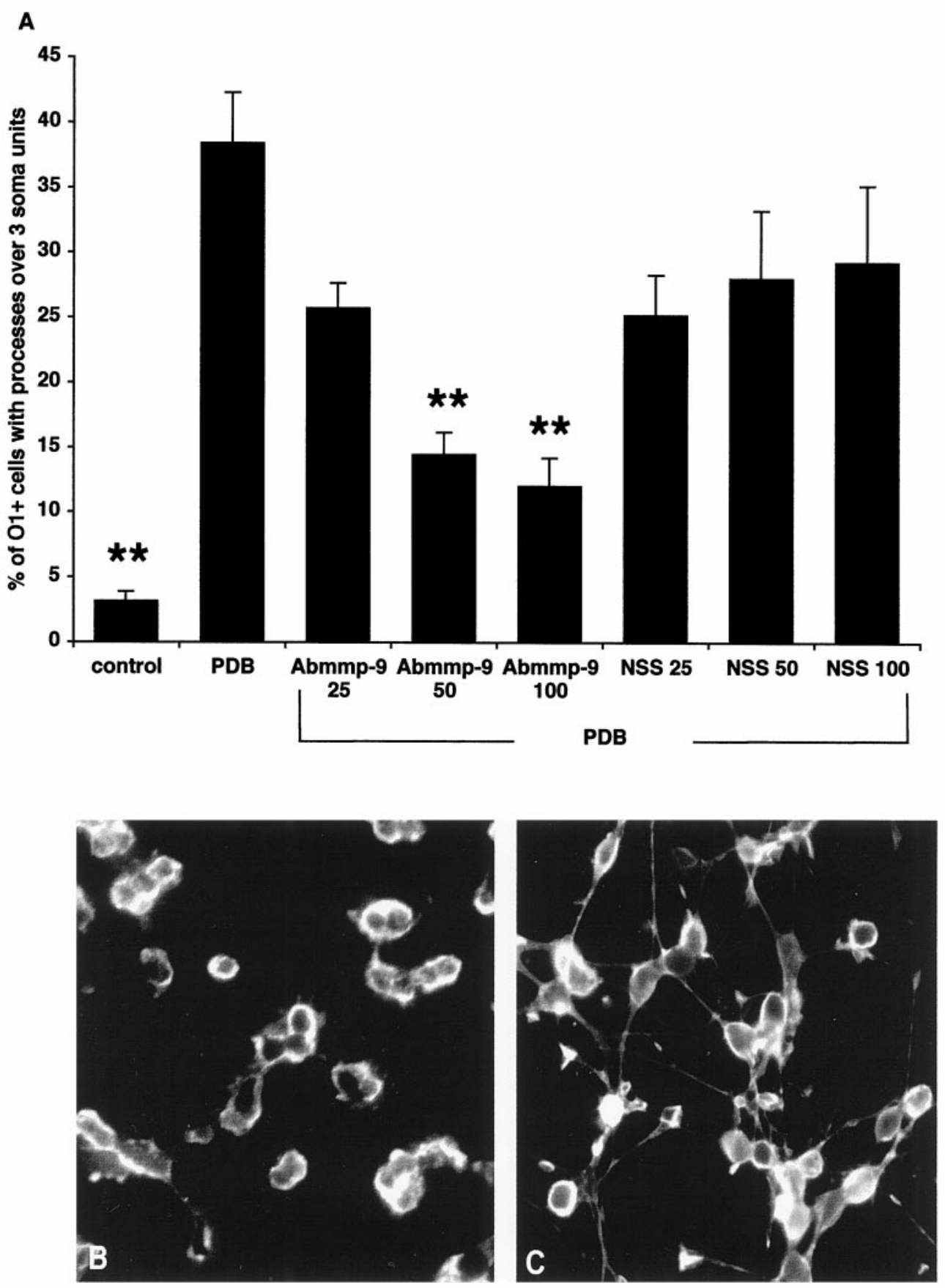

Figure 7. Effect of a neutralizing antibody to MMP-9 on process outgrowth by OLs. $A$, A neutralizing MMP-9 antibody (Abmmp-9) inhibits the PDBinduced process outgrowth by bovine OLs. The concentrations of sheep antiporcine MMP-9 and preimmune normal sheep serum (NSS) used are in micrograms per milliliter. $B$, The inhibitory effect of $A b m m p-9$ on OL process outgrowth induced by $\mathrm{PDB}$ is shown. $C$, In the absence of Abmmp-9, OLs extend significant processes in response to PDB. ${ }^{* *} p<0.001$ compared with PDB treatment alone. Scale bar, $10 \mu \mathrm{m}$.

wild-type controls, suggesting that OL maturation and myelination occur normally in the absence of MMP-9. This could be caused by compensation by another gene, and indeed, MMP-7 and -10 are upregulated in MMP-3 null mice (Rudolph-Owen et al., 1997). In the case of the MMP-9 null mice, our preliminary results indicate that MMP-12 is increased in the CNS $(\mathrm{P} . \mathrm{H}$. Larsen and V. W. Yong, unpublished observation).

In some mutations, development of the organism proceeds unimpeded, but abnormalities become manifest in adulthood or in response to various insults, when compensatory mechanisms are less dynamic or absent. For example, mice lacking GFAP develop normally (Gomi et al., 1995; Pekny et al., 1995), but late-onset (after 18 months) CNS dysmyelination occurs (Liedtke et al., 1996); the course of neuroinflammation in adult
GFAP null mice after the induction of experimental allergic encephalomyelitis (EAE) is also more severe (Liedtke et al., 1998a). Thus, to address whether OLs from adult MMP-9 null mice are impaired in their ability to regenerate processes, we cultured OLs from adult MMP-9 null mice or their wild-type controls.

Figure 9 shows that OLs derived from MMP-9 null mice had reduced capability to form processes spontaneously, when compared with OLs from wild-type mice. Furthermore, although wild-type OLs promoted process outgrowth in response to PDB, it was noted that OLs from MMP-9 null mice did not respond to stimulation. The results indicate that MMP-9 is required for both basal and PDB-induced process formation by OLs cultured from the adult brain. 

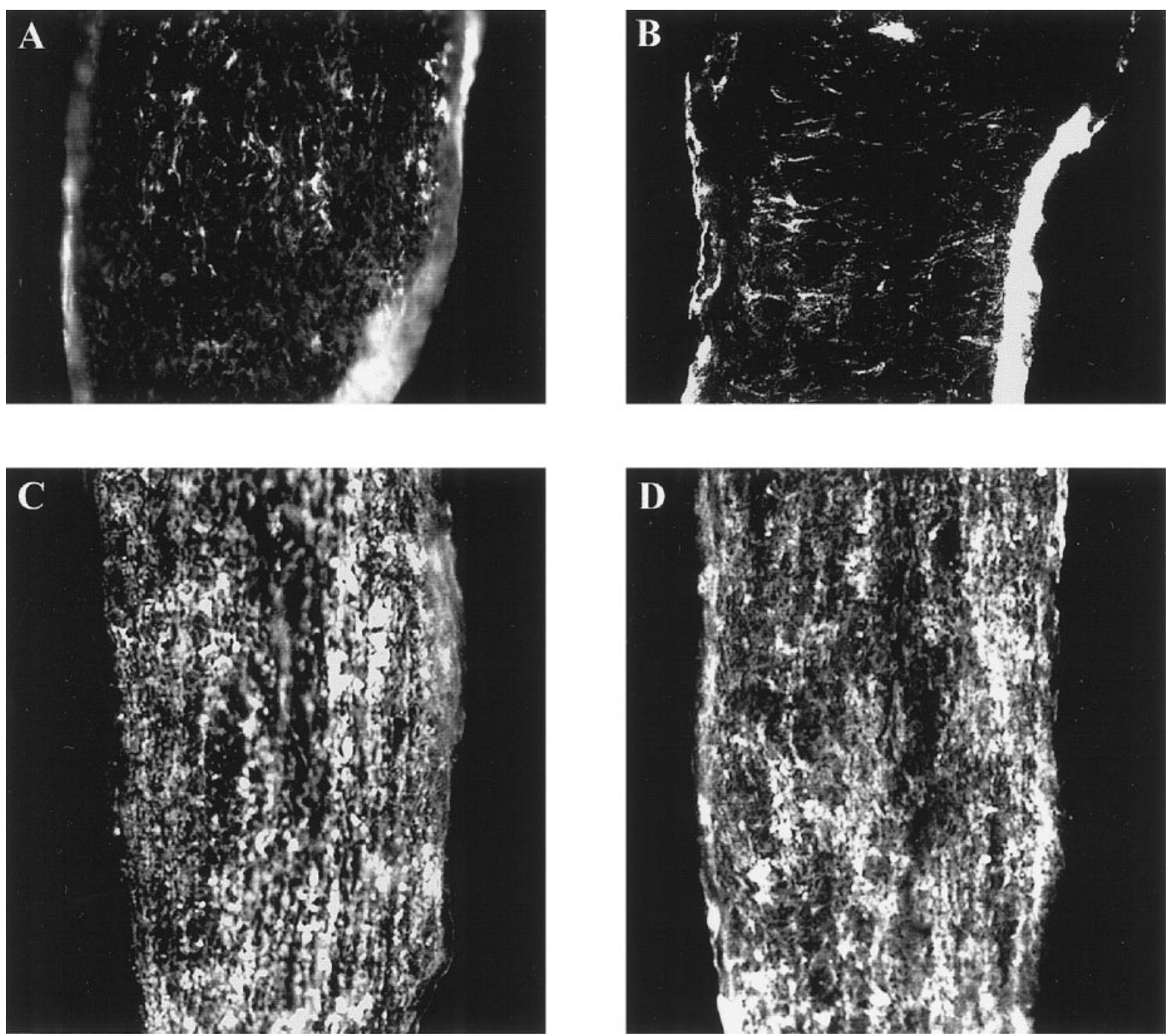

Figure 8. Comparable myelin formation during the development of the optic nerve of MMP-9 null mice and their wild-type controls. $A$, $C$, Optic nerves from wild-type controls at $\mathrm{P} 7$ and $\mathrm{P} 10$, respectively. $B, D$, Optic nerves from MMP-9 null mice at $\mathrm{P} 7$ and $\mathrm{P} 10$, respectively. MBP immunoreactivity of the optic nerves from MMP-9 null mice suggests that developmental myelination occurs normally in the absence of MMP-9.

\section{DISCUSSION}

Proteases are recognized to be of increasing importance in the regulation of development and physiology of the nervous system (Woessner, 1994; Yong et al., 1998). Migration of neural progenitor cells appears to be an MMP-mediated process (Amberger et al., 1997). Angiogenesis during CNS development is also associated with MMPs (Canete-Soler et al., 1995). MMPs are implicated in promoting neurite outgrowth and growth cone extension. Growth factors such as nerve growth factor and FGFs induced MMP expression in correspondence with promoting neurite outgrowth (Machida et al., 1989; Muir, 1994), whereas MMP inhibitors attenuate growth cone activity (Sheffield et al., 1994). MMP-2 is localized to the growth cones of dorsal root ganglion neurons, where it is thought to degrade growth inhibitory chondroitin sulfate proteoglycans, thus facilitating neurite extension (Zuo et al., 1998). Proteinases have also been implicated in long-term potentiation and synaptic growth (Baranes et al., 1998).

In this study, we show that MMPs facilitate process extension by the OL in the CNS. We first found that myelin formation in the developing mouse optic nerve is accompanied by increased MMP-9 levels. Correspondingly, TIMP-3 levels are also upregu- lated during this period. The simultaneous presence of MMP-9 and its TIMP inhibitor necessitates analyses of whether there was net proteolytic activity. In this regard, in situ zymography of the optic nerve demonstrates that net active proteolysis was occurring during myelin formation. There was not a complete overlap of in situ zymography signal with MBP immunoreactivity in the mouse optic nerve, likely because MBP immunoreactivity does not discriminate the different individual stages of myelin formation. OL processes that have completely ensheathed axons, but before compaction to extrude their cytoplasm (for review, see McLaurin and Yong, 1995), could still be MBP immunoreactive but may no longer require MMPs to remodel the microenvironment. To analyze the function of MMP-9 we used cultured OLs. We found that the enhancement of process outgrowth by PDB in adult brain-derived OLs was accompanied by increased MMP-9 expression and was blocked by TIMP-1 or a function-blocking antibody to MMP-9. Gelatinolytic activity was present at the tip of the advancing OL processes in vitro, consistent with a function for MMP-9 in mediating remodeling interactions at the advancing tip. Furthermore, OLs cultured from mice with a genetically targeted null mutation in MMP-9 exhibited a reduced capacity to 

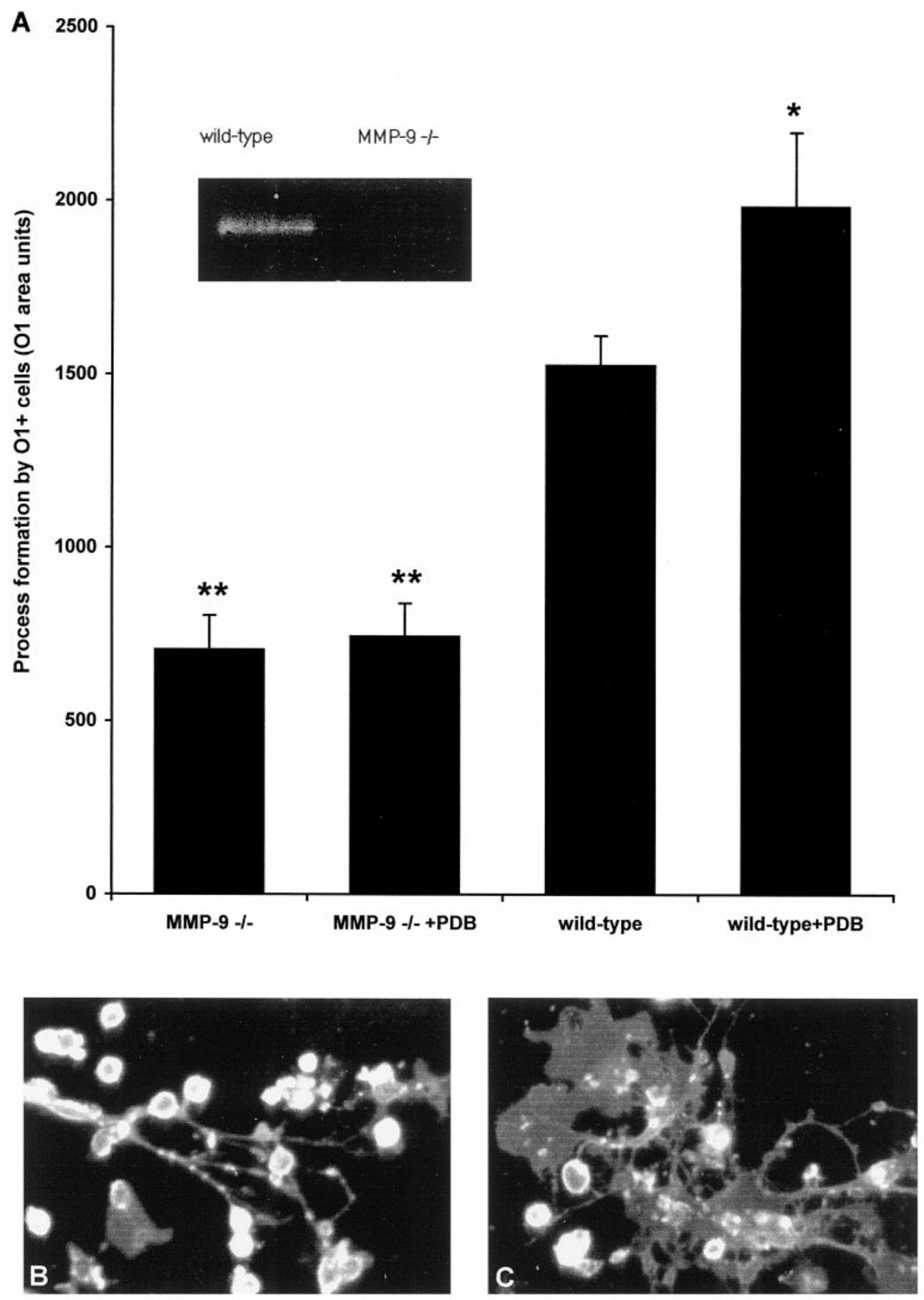

Figure 9. Effect of a targeted mutation in MMP-9 on process extension by OLs in culture. $A$, OLs derived from MMP-9 null mice exhibit a reduced capacity to extend processes compared with OLs from wild-type mice, either under basal culture conditions or in response to 10 nM PDB. ${ }^{*} p<0.05$ and ${ }^{* *} p<0.001$ compared with wild type. Inset, A zymogram demonstrates the lack of MMP-9 in MMP-9 null mice compared with that in wild type. $B$, A photograph of OLs from MMP-9 null mice after $48 \mathrm{hr}$ of PDB treatment is shown. $C$, Corresponding PDB-treated OLs from wildtype controls are displayed.

form processes. Collectively, these results implicate MMP-9 in mediating process outgrowth by OLs.

It is noteworthy that the active gelatinolytic signals seen by in situ zymography are localized to the surface of OL processes. This is consistent with observations that, although MMPs are secreted molecules, they are localized to the pericellular areas where they are required, rather than being diffusely distributed to effect widespread destruction. Although little is known about receptors for MMP-9, others have shown that MMPs can be restricted to the pericellular areas by binding to cell surface integrin receptors (Brooks et al., 1996) or to transmembrane forms of MMPs (for review, see Murphy and Knauper, 1997); interaction with CD44 may be another mechanism to localize MMP activity to the cell surface (Yu and Stamenkovic, 1999). A requirement of this cellular localization of active MMP-9 may explain the lack of facilitation of OL process outgrowth when active MMP-9 was added directly to the culture medium of OLs. In support of this interpretation, Deryugina et al. (1998) have reported that cell-associated, rather than soluble, MMP-2 mediates the contraction of polymerized collagen gels by glioma cells.

Because of the cell surface localization, it is of further interest that gelatinolytic activity was uniformly distributed along the OL soma as well as the processes. Although the latter distribution is likely used to extend processes, the reason for the cell soma 
distribution is unclear. In contrast, gelatinolytic activity in another cell type, BHK cells, was punctate and at specific sites reminiscent of "invadopodia," which are sites of interface of cells with substrate (Monsky et al., 1993, 1994). These results are in keeping with immunocytochemical data showing that MMPs are distributed both on neurites and on neuronal cell bodies (Zuo et al., 1998). A plausible role for these cell surface MMPs may be the release of growth factors that are anchored on the ECM. In this way the MMPs in the vicinity of OL somata could promote OL survival.

Although our results show a beneficial role for MMPs in CNS development and regeneration, MMPs are highly expressed in pathological processes of the nervous system, including Alzheimer's disease, stroke, malignant gliomas, and MS (for review, see Yong et al., 1998). When MMP-2 is administered by intracerebral injection, severe blood-brain barrier breach results with accompanying edema and hemorrhage (Rosenberg et al., 1992). In MS, MMPs are upregulated in the CNS during inflammation and are expressed predominantly by perivascular leukocytes or parenchymal microglia (Cuzner et al., 1996; Maeda and Sobel, 1996; Anthony et al., 1997; Cossins et al., 1997). Indeed, several synthetic inhibitors of MMPs alleviate inflammation and disease in animals afflicted with EAE, a model of MS (Gijbels et al., 1994; Hewson et al., 1995; Matyszak and Perry, 1996; Liedtke et al., 1998b). Moreover, MMP-7 and MMP-9 appear to be used by inflammatory cells to infiltrate into the CNS (Stuve et al., 1996; Kieseier et al., 1998; Liedtke et al., 1998b). Recently, Belien et al. (1999) reported that the expression of membrane-type 1 MMP confers on glioma cells the ability to degrade myelin inhibitory proteins and to invade along CNS myelin. Thus, whether or not MMPs are beneficial or detrimental may depend on several factors, including the cellular sources, the pericellular environment, the specific MMP in question, and the stage of lesion development in the disease. Therefore, it is essential to determine the specific roles of MMPs and their participation at different stages of disease development or recovery. The indiscriminate use of MMP inhibitors may control detrimental activity of MMPs (e.g., in inflammation) but may, in the longer term, also inhibit repair.

\section{REFERENCES}

Althaus HH, Klöppner S, Schmidt-Schultz T, Schwartz P (1992) Nerve growth factor induces proliferation and enhances fiber regeneration in oligodendrocytes isolated from adult pig brain. Neurosci Lett 135:219-223.

Amberger VR, Avellana-Adalid V, Hensel T, Baron-van EA, Schwab ME (1997) Oligodendrocyte-type 2 astrocyte progenitors use a metalloendoprotease to spread and migrate on CNS myelin. Eur J Neurosci 9:151-162.

Anthony DC, Ferguson B, Matyzak MK, Miller KM, Esiri MM, Perry VH (1997) Differential matrix metalloproteinase expression in cases of multiple sclerosis and stroke. Neuropathol Appl Neurobiol 23:406-415.

Balasingam V, Yong VW (1996) Attenuation of astroglial reactivity by interleukin-10. J Neurosci 16:2945-2955.

Bansal R, Pfeiffer SE (1997) FGF-2 converts mature oligodendrocytes to a novel phenotype. J Neurosci Res 50:215-228.

Bansal R, Warrington AE, Gard AL, Ranscht B, Pfeiffer SE (1989) Multiple and novel specificities of monoclonal antibodies O1, O4, and $\mathrm{R}-\mathrm{mAb}$ used in the analysis of oligodendrocyte development. J Neurosci Res 24:548-557.

Baranes D, Lederfein D, Huang YY, Chen M, Bailey CH, Kandel ER (1998) Tissue plasminogen activator contributes to the late phase of LTP and to synaptic growth in the hippocampal mossy fiber pathway. Neuron 21:813-825.

Belien ATJ, Paganetti PA, Schwab ME (1999) Membrane-type 1 matrix metalloproteinase (MT1-MMP) enables invasive migration of glioma cells in central nervous system white matter. J Cell Biol 144:373-384.

Boutros T, Croze E, Yong VW (1997) Interferon-beta is a potent promoter of nerve growth factor production by astrocytes. J Neurochem 69:939-946.

Braun PE, Sandillon F, Edwards A, Matthieu JM, Privat A (1988) Immunocytochemical localization by electron microscopy of $2^{\prime} 3^{\prime}$-cyclic nucleotide $3^{\prime}$-phosphodiesterase in developing oligodendrocytes of normal and mutant brain. J Neurosci 8:3057-3066.

Brooks PC, Stromblad S, Sanders SL, von Schalscha TL, Aimes RT, Stetler-Stevenson WG, Quigley JP, Cheresh DA (1996) Localization of matrix metalloproteinase MMP-2 to the surface of invasive cells by interaction with integrin alpha v beta 3. Cell 85:683-693.

Canete-Soler R, Gui YH, Linask KK, Muschel RJ (1995) MMP-9 (gelatinase B) mRNA is expressed during mouse neurogenesis and may be associated with vascularization. Dev Brain Res 88:37-52.

Cossins JA, Clements JM, Ford J, Miller KM, Pigott R, Vos W, Van DV, De Groot CJ (1997) Enhanced expression of MMP-7 and MMP-9 in demyelinating multiple sclerosis lesions. Acta Neuropathol (Berl) 94:590-598.

Cuzner ML, Gveric D, Strand C, Loughlin AJ, Paemen L, Opdenakker G (1996) The expression of tissue type plasminogen activator, matrix metalloproteases and endogenous inhibitors in the central nervous system in multiple sclerosis: comparison of stages in lesion evolution. J Neuropathol Exp Neurol 55:1194-1204.

Deryugina EI, Bourdon MA, Reisfeld RA, Strongin A (1998) Remodeling of collagen matrix by human tumor cells requires activation and cell surface association of matrix metalloproteinase-2. Cancer Res 58:3743-3750.

Foran DR, Peterson AC (1992) Myelin acquisition in the central nervous system of the mouse revealed by an MBP-Lac Z transgene. J Neurosci 12:4890-4897.

Gard AL, Pfeiffer SE (1990) Two proliferative stages of the oligodendrocyte lineage (A2B5+O4- and $\mathrm{O} 4+\mathrm{GalC}-$ ) under different mitogenic control. Neuron 5:615-625.

Ghatak NR (1992) Occurrence of oligodendrocytes within astrocytes in demyelinating lesions. J Neuropathol Exp Neurol 51:40-46.

Ghatak NR, Leshner RT, Price AC, Felton WL (1989) Remyelination in the human central nervous system. J Neuropathol Exp Neurol 48:507-518.

Gijbels K, Galardy RE, Steinman L (1994) Reversal of experimental autoimmune encephalomyelitis with a hydroxamate inhibitor of matrix metalloproteases. J Clin Invest 94:2177-2182.

Gomi H, Yokoyama T, Fujimoto K, Ikeda T, Katoh A, Itoh T, Itohara S (1995) Mice devoid of the glial fibrillary acidic protein develop normally and are susceptible to scrapie prions. Neuron 14:29-41.

Hewson AK, Smith T, Leonard JP, Cuzner ML (1995) Suppression of experimental allergic encephalomyelitis in the Lewis rat by the matrix metalloproteinase inhibitor Ro31-9790. Inflamm Res 44:345-349.

Kieseier BC, Clements JM, Pischel HB, Wells GM, Miller K, Gearing AJ, Hartung HP (1998) Matrix metalloproteinases MMP-9 and MMP-7 are expressed in experimental autoimmune neuritis and the Guillain-Barre syndrome. Ann Neurol 43:427-434.

Kossakowska AE, Edwards DR, Lee SS, Urbanski LS, Stabbler AL, Zhang CL, Phillips BW, Zhang Y, Urbanski SJ (1998) Altered balance between matrix metalloproteinases and their inhibitors in experimental biliary fibrosis. Am J Pathol 153:1895-1902.

Leco KJ, Khokha R, Pavloff N, Hawkes SP, Edwards DR (1994) Tissue inhibitor of metalloproteinases-3 (TIMP-3) is an extracellular matrixassociated protein with a distinctive pattern of expression in mouse cells and tissues. J Biol Chem 269:9352-9360.

Librach CL, Werb Z, Fitzgerald ML, Chiu K, Corwin NM, Esteves RA, Grobelny D, Galardy R, Damsky CH, Fisher SJ (1991) 92-kD type IV collagenase mediates invasion of human cytotrophoblasts. J Cell Biol 113:437-449.

Liedtke W, Edelmann W, Bieri PL, Chiu F-C, Cowan NJ, Kucherlapati R, Raine CS (1996) GFAP is necessary for the integrity of CNS white matter architecture and long-term maintenance of myelination. Neuron 17:607-615.

Liedtke W, Edelmann W, Chiu F-C, Kucherlapati R, Raine CS (1998a) Experimental autoimmune encephalomyelitis in mice lacking glial fibrillary acidic protein is characterized by a more severe clinical course and an infiltrative central nervous system lesion. Am J Pathol 152:251-259.

Liedtke W, Cannella B, Mazzaccaro RJ, Clements JM, Miller KM, 
Wucherpfennig KW, Gearing AJ, Raine CS (1998b) Effective treatment of models of multiple sclerosis by matrix metalloproteinase inhibitors. Ann Neurol 44:35-46.

Ludwin SK (1989) Evolving concepts and issues in remyelination. Dev Neurosci 11:140-148.

Machida CM, Rodland KD, Matrisian L, Magun BE, Ciment G (1989) NGF induction of the gene encoding the protease transin accompanies neuronal differentiation in PC12 cells. Neuron 2:1587-1596.

Maeda A, Sobel RA (1996) Matrix metalloproteinases in the normal human central nervous system, microglial nodules, and multiple sclerosis lesions. J Neuropathol Exp Neurol 55:300-309.

Matyszak MK, Perry VH (1996) Delayed-type hypersensitivity lesions in the central nervous system are prevented by inhibitors of matrix metalloproteinases. J Neuroimmunol 69:141-149.

McGuire PG, Seeds NW (1990) Degradation of underlying extracellular matrix by sensory neurons during neurite outgrowth. Neuron 4:633-642.

McLaurin J, Yong VW (1995) Oligodendrocytes and myelin. In: Neurologic clinics of North America: multiple sclerosis (Antel JP, ed), pp 23-49. Philadelphia: Saunders.

Monard D (1988) Cell-derived proteases and protease inhibitors as regulators of neurite outgrowth. Trends Neurosci 11:541-544.

Monsky WL, Kelly T, Lin CY, Yeh Y, Stetler-Stevenson WG, Mueller SC, Chen WT (1993) Binding and localization of M(r) 72,000 matrix metalloproteinase at cell surface invadopodia. Cancer Res 53:3159-3164.

Monsky WL, Lin CY, Aoyama A, Kelly T, Akiyama SK, Mueller SC, Chen WT (1994) A potential marker protease of invasiveness, seprase, is localized on invadopodia of human malignant melanoma cells. Cancer Res 54:5702-5710.

Muir D (1994) Metalloproteinase-dependent neurite outgrowth within a synthetic extracellular matrix is induced by nerve growth factor. Exp Cell Res 210:243-252.

Murphy G, Knauper V (1997) Relating matrix metalloproteinase structure to function: why the "hemopexin" domain? Matrix Biol 15:511-518.

Nagase H (1997) Activation mechanisms of matrix metalloproteinases. Biol Chem 378:151-160.

Oh LY, Yong VW (1996) Astrocytes promote process outgrowth by adult human oligodendrocytes in vitro through interaction between bFGF and astrocyte extracellular matrix. Glia 17:237-253.

Oh LY, Goodyer CG, Olivier A, Yong VW (1997) The promoting effects of bFGF and astrocyte extracellular matrix on process outgrowth by adult human oligodendrocytes are mediated by protein kinase C. Brain Res 757:236-244.

Pekny M, Leveen P, Pekna M, Eliasson C, Berthold C-H, Westermark B, Betsholtz C (1995) Mice lacking glial fibrillary acidic protein display astrocytes devoid of intermediate filaments but develop and reproduce normally. EMBO J 14:1590-1598.

Prineas JW, Kwon EE, Goldenberg PZ, Ilyas AA, Quarles RH, Benjamins JA, Sprinkle TJ (1989) Multiple sclerosis. oligodendrocyte proliferation and differentiation in fresh lesions. Lab Invest 61:489-503.
Raine CS, Wu E (1993) Multiple sclerosis: remyelination in acute lesions. J Neuropathol Exp Neurol 52:199-204.

Rosenberg GA, Kornfeld M, Estrada E, Kelley RO, Liotta LA, StetlerStevenson WG (1992) TIMP-2 reduces proteolytic opening of bloodbrain barrier by type IV collagenase. Brain Res 576:203-207.

Rudolph-Owen LA, Hulboy DL, Wilson CL, Mudgett J, Matrisian LM (1997) Coordinate expression of matrix metalloproteinase family members in the uterus of normal, matrilysin-deficient, and stromelysin1-deficient mice. Endocrinology 138:4902-4911.

Sheffield JB, Krasnopolsky V, Dehlinger E (1994) Inhibition of retinal growth cone activity by specific metalloproteinase inhibitors in vitro. Dev Dyn 200:79-88.

Sommer I, Schachner M (1981) Monoclonal antibodies (O1 to O4) to oligodendrocyte cell surfaces: an immunocytological study in the central nervous system. Dev Biol 83:311-327.

Stuve O, Dooley NP, Uhm JH, Antel JP, Francis GS, Williams G, Yong VW (1996) Interferon beta $1 \mathrm{~b}$ decreases the migration of T lymphocytes in vitro: effects on matrix metalloproteinase 9. Ann Neurol 40:853-863.

Uhm JH, Dooley NP, Oh LY, Yong VW (1998) Oligodendrocytes utilize a matrix metalloproteinase, MMP-9, to extend processes along an astrocyte extracellular matrix. Glia 22:53-63.

Vu TH, Shipley JM, Bergers G, Berger JE, Helms JA, Hanahan D, Shapiro SD, Senior RM, Werb Z (1998) MMP-9/gelatinase B is a key regulator of growth plate angiogenesis and apoptosis of hypertrophic chondrocytes. Cell 93:411-422.

Woessner Jr JF (1994) The family of matrix metalloproteinases. Ann NY Acad Sci 732:11-21.

Wu E, Raine C, Raine CS (1992) Multiple sclerosis: interaction between oligodendrocytes and hypertrophic astrocytes and their occurrence in other, nondemyelinating conditions. Lab Invest 67:88-99.

Yong VW, Antel JP (1997) Culture of glial cells from human brain biopsies. In: Protocols for neural cell culture (Fedoroff S, Richardson A, eds), pp 81-96. Totowa, NJ: Humana.

Yong VW, Cheung JC, Uhm JH, Kim SU (1991) Age-dependent decrease of process formation by cultured oliogodendrocytes is augmented by protein kinase C stimulation. J Neurosci Res 29:87-99.

Yong VW, Dooley NP, Noble PG (1994) Protein kinase C in cultured adult human oligodendrocytes: a potential role for isoform alpha as a mediator of process outgrowth. J Neurosci Res 39:83-96.

Yong VW, Krekoski CA, Forsyth PA, Bell R, Edwards DR (1998) Matrix metalloproteinases and diseases of the CNS. Trends Neurosci 21:75-80.

Yu Q, Stamenkovic I (1999) Localization of matrix metalloproteinase 9 to the cell surface provides a mechanism for CD44-mediated tumor invasion. Genes Dev 13:35-48.

Zuo J, Ferguson TA, Hernandez YJ, Stetler-Stevenson WG, Muir D (1998) Neuronal matrix metalloproteinase-2 degrades and inactivates a neurite-inhibiting chondroitin sulfate proteoglycan. J Neurosci 18 : $5203-5211$ 